\title{
Chromosome number and microsporogenesis of two accessions of Brachiaria dura Stapf (Poaceae)
}

\author{
Claudiceia Risso-Pascotto ${ }^{1}$, Maria Suely Pagliarini ${ }^{1,3}$ \& Cacilda Borges do Valle ${ }^{2}$ \\ ${ }^{1}$ Departamento de Biologia Celular e Genética, Universidade Estadual de Maringá - UEM, \\ CEP 87020-900, Maringá, PR, Brazil \\ ${ }^{2}$ Embrapa Gado de Corte, \\ CP 154, CEP 79002-970, Campo Grande, MS, Brazil \\ ${ }^{3}$ Corresponding author: Maria Suely Pagliarini, e-mail: mspagliarini@uem.br
}

RISSO-PASCOTTO, C., PAGLIARINI, M.S. \& VALLE, C.B. Chromosome number and microsporogenesis of two accessions of Brachiaria dura Stapf (Poaceae). Biota Neotrop., 9(2): http://www.biotaneotropica.org. br/v9n2/en/abstract?short-communication+bn00709022009.

Abstract: The two accessions of $B$. dura analyzed (DU01 and DU02) are hexaploid ( $2 \mathrm{n}=6 \mathrm{x}=54$ ), derived from $\mathrm{x}=9$. Meiotic abnormalities, such as precocious chromosome migration to the poles, laggards and micronuclei, were recorded in low frequency in both accessions. The few multivalent chromosome association at diakinesis and meiotic stability suggested that hexaploidy probably resulted from chromosome doubling. In DU02, chromosome transfer (cytomixis) among meiocytes, involving part or the entire genome was observed. The implication of these findings for the Brachiaria breeding is discussed.

Keywords: Brachiaria dura, meiosis, chromosome number, cytomixis.

RISSO-PASCOTTO, C., PAGLIARINI, M.S. \& VALLE, C.B. Número de cromossomos e microsporogênese de dois acessos de Brachiaria dura Stapf (Poaceae). Biota Neotrop., 9(2): http://www.biotaneotropica.org.br/ v9n2/pt/abstract?short-communication+bn00709022009.

Resumo: Os dois acessos de $B$. dura analisados (DU01 e DU02) são hexaplóides $(2 \mathrm{n}=6 \mathrm{x}=54)$, derivados de $\mathrm{x}=9$. Anormalidades meióticas como migração precoce de cromossomos para os polos, cromossomos retardatários e micronúcleos foram observados em baixa frequência em ambos os acessos. A presença de poucas associações cromossômicas em diacinese e a estabilidade meiótica sugere que a hexaploidia provavelmente resultou de duplicação cromossômica. No acesso DU02 observou-se transferência de cromossomos (citomixia) entre meiócitos, envolvendo parte ou todo o genoma. As implicações destes resultados para o melhoramento de Brachiaria são discutidas.

Palavras-chave: Brachiaria dura, citomixia, número de cromossomos, meiose. 


\section{Introduction}

Although Brachiaria dura Stapf is adapted to sandy soils of low fertility (Verboom 1966) and may have potential as forage for dry areas (Skerman \& Riveros 1990), the two accessions of this species available in the collection at CIAT (International Center for Tropical Agriculture, Colombia) show little promise as pasture species, because they have poor vigor and very narrow, convolute leaf blades (Keller-Grein et al. 1996). It is a species recommended for future collecting efforts in Africa (Keller-Grein et al. 1996). According to the taxonomic classification for the genus Brachiaria (Renvoize et al. 1996), B. dura belongs to Group 5, where the most important commercial Brachiaria species such as B. brizantha, B. decumbens, and $B$. ruziziensis were placed. Species of this group present: i) few to several racemes scattered along a central axis, ascending or spreading; ii) broad or narrow rachis, ribbon-like or crescentic, one-sided; iii) spikelets solitary, on short pedicels, forming one or two crescentic rows, dense, spreading; iv) lower glume, cuff-like and upper lemma, granulose.

Agronomic and morphologic informations about Brachiaria have been generated from one or few genotypes per species (Miles et al. 1996). Little attention was paid to natural variation because no large germplasm collections were available until the 1980's when a major collecting trip was undertaken by CIAT with participation of African institutions (Keller-Grein et al. 1996). Cytogenetic studies have been intensively developed in the Brazilian Brachiaria collection. Chromosome counting and evaluation of meiotic behavior were performed for B. brizantha (Mendes-Bonato et al. 2002), B. nigropedata (Utsunomiya et al. 2005), B. jubata (Mendes-Bonato et al., 2006), and B. dictyoneura (Risso-Pascotto et al. 2006a).

This investigation determined the chromosome number and evaluated the meiotic behavior in two accessions of $B$. dura. It is a contribution to the breeding program underway in the Brachiaria genus to obtain new cultivars for the American tropical areas.

\section{Materials and Methods}

Two accessions of B. dura (DU01 and DU02) available at the Brazilian Brachiaria germplasm collection maintained by Embrapa Beef Cattle Research Center (Campo Grande, MS, Brazil) were evaluated. Both accessions were collected in the wild East African savannas in the 1980 s by the International Center for Tropical Agriculture (CIAT, Colombia), transferred to Embrapa Genetic Resources and Biotechnology (Brazil), and then to Campo Grande. They are being maintained in the field, where site characteristics of cultivation at the Embrapa Beef Cattle Research Center at Campo Grande, Mato Grosso do Sul, Brazil are: i) climate: climate type Aw; tropical humid savanna; average annual precipitation $=1526 \mathrm{~mm}$; average temperature $=22^{\circ} \mathrm{C}$; altitude $520 \mathrm{~m}$; latitude $=20^{\circ} 28^{\prime} \mathrm{S}$; longitude $=55^{\circ} 40^{\prime} \mathrm{W}$; ii) soil: poor dark red Latossol soil composed of $59 \%$ sand; $8 \%$ silt and $33 \%$ clay; $\mathrm{pH}=4.2$.

Inflorescences for the meiotic study were collected in 16 clonal plants representing each accession and fixed in a mixture of $95 \%$ ethanol, chloroform and propionic acid (6:3:2) for 24 hours, transferred to $70 \%$ alcohol and stored under refrigeration until use. Microsporocytes were prepared by squashing and staining with $0.5 \%$ propionic carmine. Photomicrographs were taken in a Wild Leitz microscope using Kodak Imagelink - HQ, ISO 25 black and white film.

\section{Results and Discussion}

Chromosome countings at diakinesis (Figure 1a and 2a) and anaphase I revealed that both accessions are hexaploid $(2 n=6 x=54)$ and derived from $\mathrm{x}=9$. In the genus Brachiaria, two basic chromosome
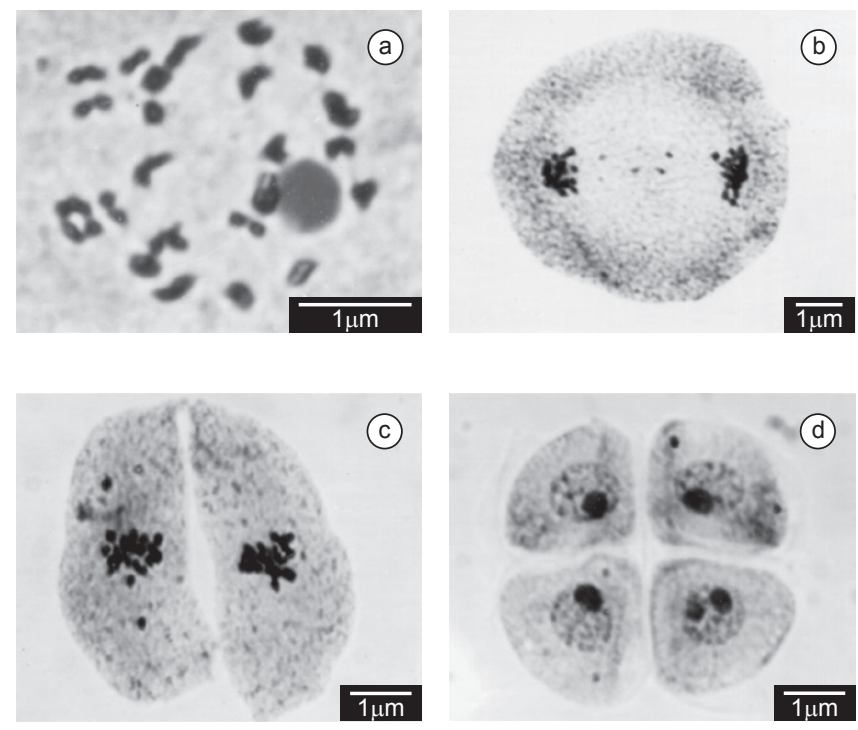

Figure 1. Aspects of microsporogenesis in Brachiaria dura accession DU01 $(2 n=6 x=54)$. a) Diakinesis with bivalents and multivalents; b) Early telophase I with micronuclei; c) Metaphase II with precocious chromosome migration to the poles in one cell; d) Tetrad with a micronucleus in one microspore.

Figura 1. Aspectos da microsporogênese no acesso DU01 $(2 \mathrm{n}=6 \mathrm{x}=54)$ de Brachiaria dura. a) Diacinese com bivalentes e multivalentes. b) Telófase I inicial com micronúcleos. c) Metáfase II com migração precoce de cromossomos para os polos em uma célula. d) Tétrade com micronúcleos em um micrósporo.
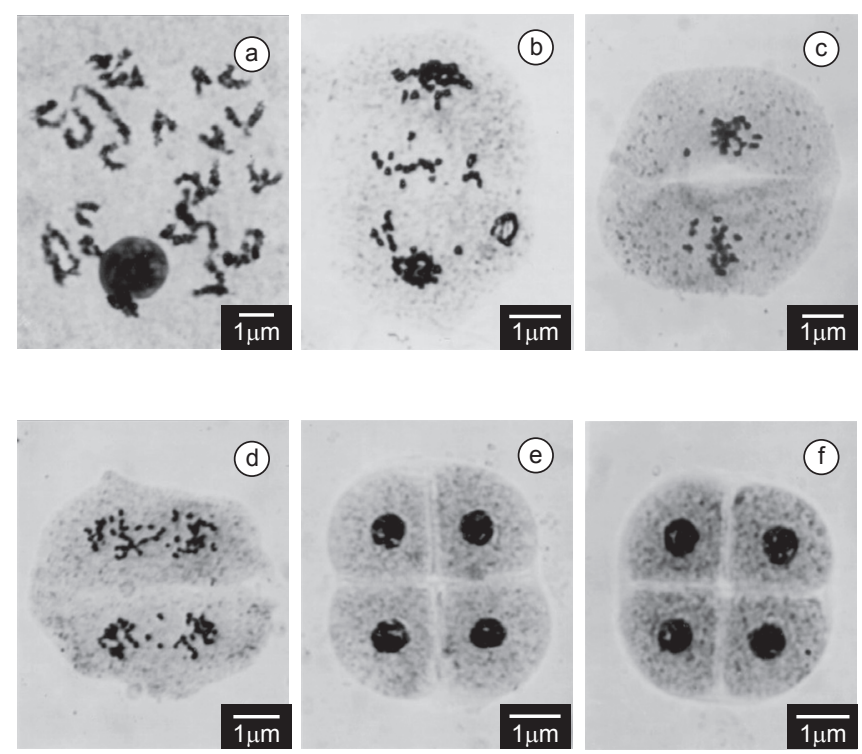

Figure 2. Aspects of microsporogenesis in Brachiaria dura accession DU02 $(2 \mathrm{n}=6 \mathrm{x}=54)$. a) Diakinesis with bivalents; b) Anaphase I with several laggards; c) Metaphase II with precocious chromosome migration to the poles in both cells; d) Anaphase II with laggards; e) Normal tetrad of microspores; and f) Tetrad with a micronucleus in one microspore.

Figura 2. Aspectos da microsporogênese no acesso DU02 $(2 n=6 x=54)$ de Brachiaria dura. a) Diacinese com bivalentes; b) Anáfase I com cromossomos retardatários; c) Metáfase II com migração precoce de cromossomos para os pólos em ambas as células; d) Anáfase II com retardatários; e) Tétrade normal de micrósporos; e f) Tétrade com micronúcleo em um micrósporo. 
numbers have been reported for decades for several species, $\mathrm{x}=7$ and $\mathrm{x}=9$ (Basappa et al. 1987, Bernini \& Marin-Morales 2001, Valle \& Savidan 1996, Mendes-Bonato et al. 2002, 2006, Utsunomiya et al. 2005). However, recently, a new basic chromosome number, $x=6$, was reported for $B$. dictyoneura, where all the accessions analyzed were tetraploid with $2 \mathrm{n}=4 \mathrm{x}=24$ (Risso-Pascotto et al. 2006b).

The available literature indicates a wide prevalence of polyploidy forms in the genus Brachiaria, with a predominance of tetraploid accessions within species (Mendes-Bonato et al. 2002, 2006, Utsunomiya et al. 2005, Risso-Pascotto et al. 2006b). Among several species studied, hexaploid accessions $(2 \mathrm{n}=6 \mathrm{x}=54)$ were recorded only in B. brizantha (Mendes-Bonato et al. 2002). Polyploidy is very common in grasses and according to Stebbins (1956), the occurrence of natural polyploidy among grasses is about $70 \%$. In the genus Brachiaria, determination of DNA content by flow cytometry revealed that about of $13 \%$ of accessions are diploid, $58 \%$ are tetraploid, $18 \%$ are pentaploid, $11 \%$ are hexaploid, and $0.5 \%$ is heptaploid (Penteado et al. 2000). DNA content on B. dura accessions was estimated to be 3.00 picogramas in DU01 and 2.67 picograms in DU02. The highest value of DNA content in the genus Brachiaria was estimated in 3.57 picogramas detected in a polyploid accession of $B$. humidicola (Penteado et al. 2000)

Evaluation of the meiotic behavior revealed a low frequency of meiotic abnormalities in both accessions, with a mean of $10.24 \%$ in DU01 and 2.92\% in DU02 (Table 1). Abnormalities recorded were those typical of polyploids, such as multivalent chromosomes association at diakinesis, although in very low frequency (Figure 1a), precocious chromosome migration to the poles in metaphases (Figures 1c, 2c), laggard chromosomes in anaphases (Figures 1b, $2 \mathrm{~b}, \mathrm{c})$, leading to micronuclei formation in telophases and tetrads (Figures 1d, 2f). In both accessions, the frequency of abnormalities decreased severely by the end of meiosis; in DU02, only $0.67 \%$ of tetrads presented micronuclei, and the remaining were totally normal (Figure 2e). The reduction of meiotic abnormalities in the second division could be explained by the inclusion of micronuclei formed in the first division in the metaphase plate of the second division, as observed in other species of the genus (Mendes-Bonato et al. 2002, 2006, Utsunomiya et al. 2005, Risso-Pascotto et al. 2006a). These abnormalities were recorded in other polyploid accessions of different species of Brachiaria (Mendes-Bonato et al. 2002, 2006, Utsunomiya et al. 2005, Risso-Pascotto et al. 2006a). However, in the hexaploid accessions of Brachiaria brizantha, the percentage of abnormalities was higher (Mendes-Bonato et al. 2002), ranging from 12 to $31 \%$. DU01 and DU02 are the most stable accessions concerning meiotic behavior among those previously analyzed by our group. The meiotic behavior of these accessions suggests that they might have resulted from chromosome doubling of a triploid parental. This assumption is based on the low frequency of multivalent chromosome association at diakinesis and a high number of meiocytes carrying only bivalents.

In Brachiaria, the fate of micronuclei at telophases seems to be genotype-specific. In some accessions, they remain as micronuclei in the tetrad, however, in others they were eliminated in microcytes (Mendes-Bonato et al. 2002, 2006, Utsunomiya et al. 2005, RissoPascotto et al. 2006a). In DU01 and DU02 micronuclei remained in the microspores of the tetrad.

Among several inflorescences analyzed, one of them in DU02, presented cytomixis among meiocytes, mainly in the early stages of prophase I, zygotene and pachytene (Figure 3). Among 258 meiocytes in these phases, $16,7 \%$ showed the phenomenon. Cytomixis had been reported in B. nigropedata (Utsunomiya et al., 2004) and in B. humidicola (Boldrini et al. 2006) with the same aspects of chromosome transfer among cells. In general, two cells were involved in the phenomenon, but some meiocytes suggested that more than two cells could be involved in the chromosome transference (Figures $3 \mathrm{c}, 3 \mathrm{f}, \mathrm{g}$ ). Figures 3a,b,d show the phenomena of chromosome transference, while Figures $3 \mathrm{c}, \mathrm{e}-\mathrm{h}$ illustrate meiocytes that received part or the entire genome of another meiocyte. Cells with abnormal chromatin content did not complete meiosis and each group of chromosomes originated micronuclei (Figure 3i).

The structural alteration of migrating chromatin observed in $B$. dura (Figure 3a-c) was also recorded in B. nigropedata (Utsunomiya et al., 2004) and in B. humidicola (Boldrini et al. 2006). According to Feijó \& Pais (1989) such agglutination eases the passage for migrating chromatin throughout a thin cytoplasm channel. Despite the number of species in which cytomixis has been reported, its origin and significance are still unknown. Its role in the evolutionary process is contradictory, because it results in the formation of hyperploid and hypoploid cells, compromising pollen fertility. The influence of cytomixis on the generation of polyploid gametes can be expected in Brachiaria, a genus where polyploidy is predominant (Valle \& Savidan 1996, Penteado et al. 2000, Mendes-Bonato et al. 2002, 2006, Utsunomiya et al. 2005, Risso-Pascotto et al. 2006a). However, when only a part of the genome is transferred, unbalanced and sterile gametes are formed.

The Brachiaria breeding program depends on hybridization both inter and intraspecific to produce novel genetic variability using sexual genotypes and pollen of selected apomictic accessions or hybrids. In the genus, polyploidy is generally associated with apomixis (Valle

Table 1. Meiotic abnormalities in two accessions of Brachiaria dura.

Tabela 1. Anormalidades meióticas em dois acessos de Brachiaria dura.

\begin{tabular}{|c|c|c|c|c|c|}
\hline \multirow[t]{2}{*}{ Phases } & \multirow[t]{2}{*}{ Abnormalities } & \multicolumn{2}{|c|}{$\begin{array}{c}\text { DU01 } \\
2 n=6 x=54\end{array}$} & \multicolumn{2}{|c|}{$\begin{array}{c}\text { DU02 } \\
2 n=6 x=54\end{array}$} \\
\hline & & $\begin{array}{c}\text { No. of PMCs } \\
\text { analyzed }\end{array}$ & $\begin{array}{l}\text { No. of abnormal } \\
\text { PMCs }(\%)\end{array}$ & $\begin{array}{c}\text { No. of PMCs } \\
\text { analyzed }\end{array}$ & $\begin{array}{l}\text { No. of abnormal } \\
\text { PMCs }(\%)\end{array}$ \\
\hline Metaphase I & Precocious chromosome migration & 154 & $11(7.14 \%)$ & 188 & $5(2.66 \%)$ \\
\hline Anaphase I & Laggard chromosomes & 146 & $27(18.49 \%)$ & 108 & $5(4.63 \%)$ \\
\hline Telophase I & Micronuclei & 152 & $8(5.26 \%)$ & 147 & $0(0.0 \%)$ \\
\hline Prophase II & Micronuclei & 146 & $6(4.11 \%)$ & 148 & $1(0.67 \%)$ \\
\hline Metaphase II & Precocious chromosome migration & 224 & $45(20.0 \%)$ & 165 & $7(4.24 \%)$ \\
\hline Anaphase II & Laggard chromosomes & 147 & $29(19.73 \%)$ & 147 & $15(10.20 \%)$ \\
\hline Telophase II & Micronuclei & 206 & $6(2.91 \%)$ & 148 & $1(0.68 \%)$ \\
\hline Tetrad & Micronuclei & 166 & $4(2.41 \%)$ & 149 & $1(0.67 \%)$ \\
\hline & Total & 1,341 & $136(10.24 \%)$ & 1,200 & $35(2.92 \%)$ \\
\hline
\end{tabular}



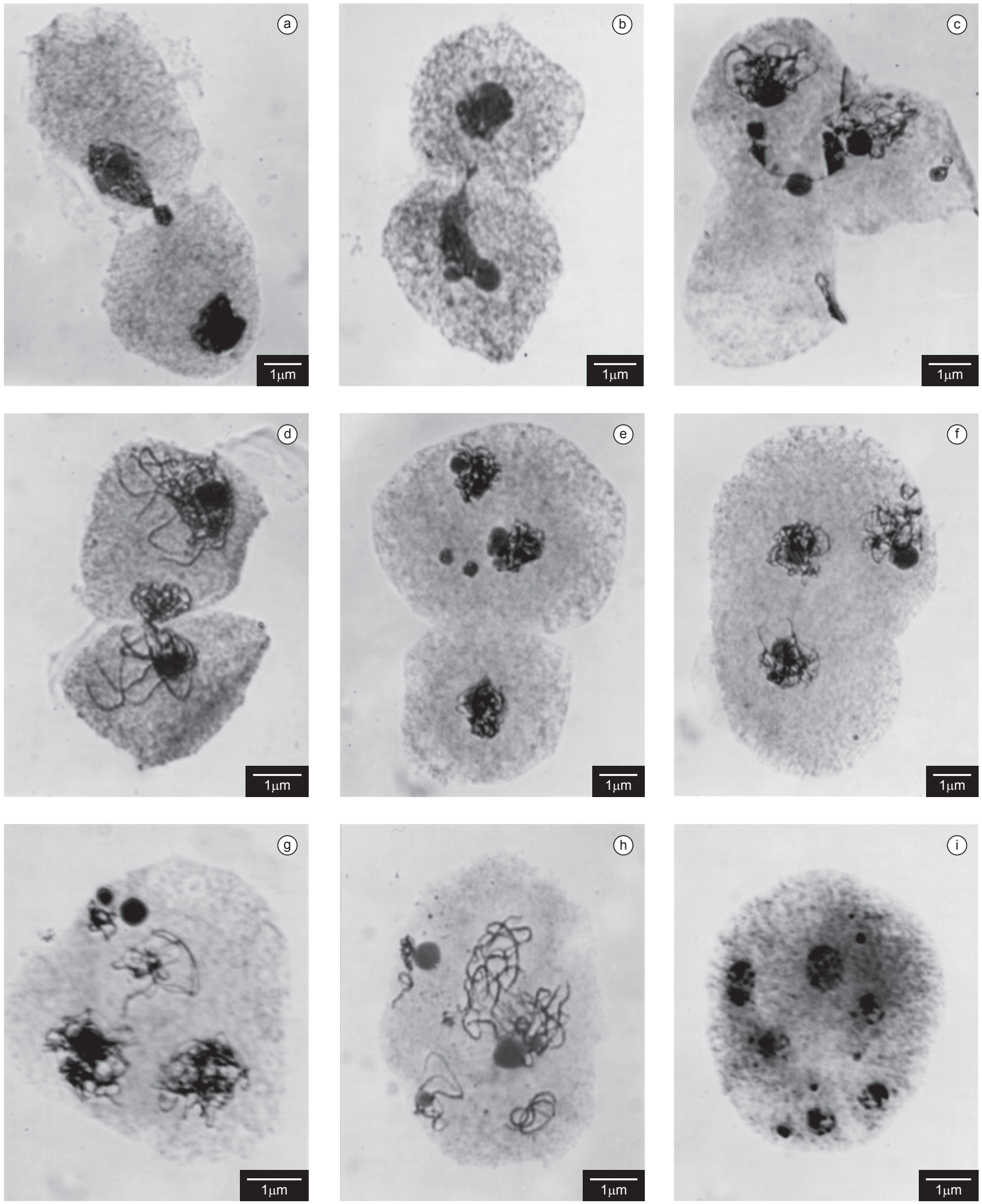

Figure 3. Aspects of chromosome transfer in Brachiaria dura accession DU02. a,b) Chromosome transfer between meiocytes with chromatin agglutination. c) Result of cytomixis among three meiocytes. d-h) Result of cytomixis between meiocytes with transference of part or the entire genome. i) Telophase I with several nuclei resulting from meiotic arrest in cells that underwent cytomixis.

Figura 3. Aspectos da transferência de cromossomos no acesso DU02 de Brachiaria dura. a,b) Transferência de cromossomos entre meiócitos com aglutinação de cromatina; c) Resultado da citomixia entre três meiócitos; d-h) Resultado da citomixia entre meiócitos com transferência de parte ou todo o genoma; i) Telófase I com micronúcleos resultantes da paralização da meiose em células que sofreram citomixia. 
\& Savidan 1996). The accessions under analysis, DU01 and DU02, are sexual (Valle \& Savidan 1996; C. B. Valle, unpublished data) and both presented a very low frequency of meiotic abnormalities, thus they are strong candidates to introgress traits of interest present in apomictic accessions or compatible species. These accessions of $B$. dura are expected to produce viable female and male gametes to be used in the hybridization program with other compatible hexaploid Brachiaria accessions.

\section{Acknowledgements}

Authors are grateful to UNIPASTO for financial support.

\section{References}

BASAPPA, G.P., MUNIYAMMA, M. \& CHINNAPPA, C.C. 1987. An investigation of chromosome numbers in the genus Brachiaria (Poaceae: Paniceae) in relation to morphology and taxonomy. Can. J. Bot. 65(11):2297-2309.

BERNINI, C. \& MARIN-MORALES, M.A. 2001. Karyotype analysis in Brachiaria (Poaceae) species. Cytobios, 104(407):157-171.

BOLDRINI, K.R., PAGLIARINI, M.S. \& VALLE, C.B. 2006. Cell fusion and cytomixis during microsporogenesis in Brachiaria humidicola (Poaceae). South Afr. J. Bot. 72(3):478-481.

FEIJÓ, J.A. \& PAIS, M.S.S. 1989. Cytomixis in meiosis during the microsporogenesis in Ophrys lutea: an ultrastructural study. Caryologia, 42:37-48.

KELLER-GREIN, G., MAASS, B.L. \& HANSON, J. 1996. Natural variation in Brachiaria and existing germoplasma collections. In Brachiaria: biology, agronomy and improvement (J.W. Miles, B.L. Maass \& C.B. Valle, eds.). Centro Internacional de Agricultura Tropical - CIAT; Empresa Brasileira de Pesquisa Agropecuária - EMBRAPA, Cali; Brasília, p. 17-42.

MENDES-BONATO, A.B., PAGLIARINI, M.S., FORLI, F., VALLE, C.B. \& PENTEADO, M.I.O. 2002. Chromosome number and microsporogenesis in Brachiaria brizantha (Gramineae). Euphytica, 125(3):419-425.

MENDES-BONATO, A.B., PAGLIARINI, M.S., RISSO-PASCOTTO, C. \& VALLE, C.B. 2006. Chromosome number and meiotic behavior in Brachiaria jubata (Gramineae). J. Genet. 85(1):83-87.
MILES, J.W., MAASS, B.L. \& VALLE C.B. 1996. Brachiaria: biology, agronomy and improvement. Centro Internacional de Agricultura Tropical - CIAT; Empresa Brasileira de Pesquisa Agropecuária - EMBRAPA, Cali; Brasília.

PENTEADO, M.I.O., SANTOS, A.C.M., RODRIGUES, I.F., VALLE, C.B., SEIXAS, M.A.C. \& ESTEVES, A. 2000. Determinação de poliploidia e avaliação da quantidade de DNA total em diferentes espécies de gênero Brachiaria. Embrapa Gado de Corte, Campo Grande.

RENVOIZE, S.A., CLAYTON, W.D., KABUYE, C.H.S. 1996. Morphology, taxonomy, and natural distribution of Brachiaria (Trin.) Griseb. In Brachiaria: biology, agronomy, and improvement (J.W. Miles, B.L. Maass \& C.B. Valle, eds.). Centro Internacional de Agricultura Tropical - CIAT; Empresa Brasileira de Pesquisa Agropecuária - EMBRAPA, Cali; Brasília, p. 1-15.

RISSO-PASCOTTO, C., PAGLIARINI, M.S. \& VALLE, C.B. 2006 a. Microsporogenesis in Brachiaria dictyoneura (Fig. \& De Not.) Stapf (Poaceae: Paniceae). Genet. Mol. Res. 5(4):837-845.

RISSO-PASCOTTO, C., PAGLIARINI, M.S. \& VALLE, C.B. 2006b. A new basic chromosome number for the genus Brachiaria (Trin.) Griseb. (Poaceae:Panicoideae:Paniceae). Genet. Res. Crop Evol. 53(1):7-10.

SKERMAN, P.J. \& RIVEROS, F. 1990. Tropical grasses. Food and Agriculture Organization - FAO, Rome.

UTSUNOMIYA, K.S., PAGLIARINI, M.S. \& VALLE, C.B. 2004. Chromosome transfer among meiocytes in Brachiaria nigropedata (Ficalho \& Hiern) Stapf (Gramineae). Cytologia, 69(4):395-398.

UTSUNOMIYA, K.S., PAGLIARINI, M.S. \& VALLE, C.B. 2005. Microsporogenesis in tetraploid accessions of Brachiaria nigropedata (Ficalho \& Hiern) Stapf (Gramineae). Biocell, 29(3):295-301.

VALLE, C.B. \& SAVIDAN, Y. 1996. Genetics, cytogenetics, and reproductive biology of Brachiaria. In Brachiaria: biology, agronomy and improvement (J.W. Miles, B.L. Maass \& C.B. Valle, eds.). Centro Internacional de Agricultura Tropical - CIAT; Empresa Brasileira de Pesquisa Agropecuária - EMBRAPA, Cali; Brasília, p. 147-163.

VERBOOM, W.C. 1966. Brachiaria dura: a promising new forage grass. J. Range Manage. 19(2):91-93. 